\title{
Morphological indicators of subcutaneous implantation of monofillament mesh
}

\author{
V. Gimranov ${ }^{*}$, E. Skovorodin, I. Abyzgildina, F. Karimov and \\ A. Bagautdinov
}

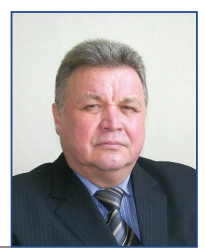

\section{Abstract}

Hernias are a significant, non-infectious animal condition. In productive animals, failure to provide surgical treatment leads to premature rejection and potential loss of their productive longevity. In small pets, this becomes a social problem for pet owners related to the keeping and death of affected animals. The aim of this study was to study the histological parameters of tissues during implantation of monofilament mesh in cattle for periods up to four months. The study was conducted on eight bulls of the Black Motley breed, divided into two groups of four animals. In the first group, four bulls received a subcutaneous implant of hernioplasty mesh made of polypropylene monofilament (Herniamesh S.R.I. Via CiRie 22 / A, San Maruro Torinese, Torino, Italy) in the area of the lateral soft abdominal wall on the right and left sides. In the second group, four bulls received implants in the middle third of the neck to the right and left sides. Thus, the subject of research was 16 wounds with implanted mesh. A sterile piece monofilament mesh, $1 \times 2 \mathrm{~cm}$ in size and folded in half along the longitudinal side, was inserted vertically into the formed hypodermic pocket on the right side of the wound, in which it was possible to freely place the specified mesh. During the course of the study,
Polycon No. 4 thread with intermittent knotted seams was used, and three sutures were applied. To ensure fixation of the mesh, it was stitched centrally. The material for histological studies was taken by biopsy at one, two, three and four months after implantation. Tissue was embedded in paraffin blocks, and sections were stained with haematoxylin-eosin and picrofuchsin according to Van Gieson. The results indicated that after subcutaneous implantation of monofilament mesh in the neck and abdominal wall in cattle, wound healing occurs by primary intention. It was revealed that from the beginning of the histological study to one month, the monofilament mesh is first overgrown with loose connective tissue. By the end of the study, after four months, this is sequentially differentiated into dense connective tissue. No significant differences were observed between the abdominal wall and neck area as sites of implantation, and morphological processes in both sites proceeded in the same way. Thus, the conducted studies allow us to conclude that monofilament mesh is a suitable material for closing the hernial ring in cattle, where it is not possible to use their own tissues for these purposes.

Key words: cell; dermis; epidermis; healing; implant

Valiyan GIMRANOV*, DVM, PhD, Full Professor, (Corresponding author: e-mail: gimranov_val@rambler. ru), Evgeny SKOVORODIN, DVM, PhD, Full Professor, Ilnara ABYZGILDINA, graduate student, Foat KARIMOV, DVM, PhD, Full Professor, Aidar BAGAUTDINOV, DVM, PhD, Full Professor, Bashkir State Agrarian University, Ufa, Russia 


\section{Introduction}

In terms of prevalence, hernias are one of the common surgical diseases in all animal species (Alban et al., 2013; Burns et al., 2013; Greber et al., 2013; Alban et al., 2015; Snell et al., 2015; Hayashi et al., 2016; Vortman and Ditl, 2016; Yun et al., 2017; Bando et al., 2018; Hodshon and Thomas, 2018; Sadan et al., 2019). This is a purely surgical problem, with no alternative to surgical treatment. The occurrence of hernias can be associated with injuries. Often the occurrence of hernias can be associated with anatomical conditions that most often occur in the navel, groin or perineum (Shnjakina and Shherbakov, 2008; Gimranov and Ljukovec, 2010, 2011; Safonov, 2018), or they may arise as a result of unsuccessful operations or their complications (Scharner et al., 2018; Winter et al., 2019).

The treatment of hernias has a long history, and progress in solving this problem was primarily associated with the development of methods of pain relief and anaesthesia during these operations, and the widespread introduction of aseptic and antiseptic methods in practice. The most important stage in the further development of hernia surgery was the development and implementation in clinical practice of various methods for closing defects using allogeneic and synthetic materials (Shnjakina and Shherbakov, 2008). However, in recent years, new experimental materials and methods for the treatment of hernias have also been proposed, in particular 3D technology for the manufacture of tissue for implantation, the use of materials based on powder technologies and other materials that are biologically safe and exhibit high compatibility with animal tissues (Aydin et al., 2018; Blázquez et al., 2018; Mobbs et al., 2018).

In modern hernia surgery, there is a strong tendency to use various materials, including autoplastic, animal and vegetable biomaterials, synthetic materials, and metal mesh materials, to close tissue defects that are the cause of hernia formation. The requirements for these materials are: strength, elasticity, inertness, asepticity, the ability to germinate with connective tissue, and do not cause encapsulation (Anurov et al., 2017; Nakayama et al., 2018; Ponce Leon et al., 2018; Bouliaris et al., 2019; Marinaro et al., 2019; Miserez et al., 2019; Sadan et al., 2019; Taguchi et al., 2019; Trevisan et al., 2019).

The aim of this study was to determine the histo-morphological changes in subcutaneous tissue during implantation of a polypropylene monofilament mesh in hernioplasty.

\section{Materials and methods}

The study was performed on two groups of bulls of the Black Motley breed. Each group contained four animals aged 6 months, selected according to the principle of analogues. All experiments were carried out in accordance with the legislation of the Russian Federation (Law of the Russian Federation "On Veterinary Medicine"; Criminal Code of the Russian Federation: Article 245 "Cruelty to Animals"; Order of the Ministry of Health of the USSR No. 755 of August 12, 1977 "On measures to further improve organizational forms of work using experimental animals") and subject to the European Convention for the Protection of Pet Animals (Council of Europe - ETS no. 125 European Convention for the Protection of Pet Animals). In the first group, four bulls received a subcutaneous implant of hernioplasty mesh made of polypropylene monofilament (Herniamesh S.R.I. Via CiRie 22 / A, San Maruro Torinese, Torino, Italy) in the area of the lateral abdominal wall on 
the right and left sides. In the second group, four bulls received the same implants, though in the middle third of the neck, on the right and left sides. For anaesthesia, Xila-Zoletil preparations were used in a dose of $0.3-0.5 \mathrm{~mL}$. For local anaesthesia, a $0.5 \%$ novocaine solution was used, with infiltration performed in layers: intradermally and subcutaneously. A sterile monofilament mesh, $1 \times 2 \mathrm{~cm}$ in size, was folded in half along the longitudinal side and inserted vertically into the formed hypodermic pocket on the right side of the wound, in which it was possible to freely place the specified mesh. During the course of the study, thread Polycon No. 4 was used with intermittent knotted seams, with the application of three sutures. The mesh was stitched centrally to ensure it was properly affixed. The operations were carried out with careful observance of the rules of asepsis and antiseptics. The material for histological examination was taken by biopsy under appropriate anaesthesia, one, two, three and four months after implantation of the mesh. The biopsy material was fixed in Carnoy fluid. Sections were made from paraffin blocks and stained with haematoxylineosin for the general morphological survey of histological preparations. Van Gieson staining was performed to differentiate collagen and muscle fibres.

Table 1. The results of implantation of monofilament mesh in cattle

\begin{tabular}{|c|c|c|c|c|c|c|}
\hline \multirow{2}{*}{$\begin{array}{l}\text { Animal } \\
\text { group }\end{array}$} & \multirow{2}{*}{$\begin{array}{l}\text { Animal } \\
\text { number }\end{array}$} & \multirow{2}{*}{$\begin{array}{l}\text { Wound } \\
\text { location }\end{array}$} & \multicolumn{4}{|c|}{$\begin{array}{l}\text { Results at analysis intervals after implantation } \\
\qquad \text { (months) }\end{array}$} \\
\hline & & & 1 & 2 & 3 & 4 \\
\hline \multirow{8}{*}{1} & \multirow{2}{*}{1} & right & + & + & + & + \\
\hline & & left & + & + & + & + \\
\hline & \multirow{2}{*}{2} & right & + & + & + & + \\
\hline & & left & + & + & + & + \\
\hline & \multirow{2}{*}{3} & right & + & + & rejection & rejection \\
\hline & & left & + & + & + & + \\
\hline & \multirow{2}{*}{4} & right & + & + & + & + \\
\hline & & left & + & + & + & + \\
\hline \multirow{8}{*}{2} & \multirow{2}{*}{5} & right & + & + & + & + \\
\hline & & left & + & + & + & + \\
\hline & \multirow{2}{*}{6} & right & + & + & + & + \\
\hline & & left & + & + & rejection & rejection \\
\hline & \multirow{2}{*}{7} & right & + & + & + & + \\
\hline & & left & + & + & + & + \\
\hline & \multirow{2}{*}{8} & right & + & + & + & + \\
\hline & & left & + & + & + & + \\
\hline & \multicolumn{2}{|l|}{ Total } & 16 & 16 & $\begin{aligned}+ & =14 \\
& \text { rejection }=2\end{aligned}$ & $\begin{aligned}+ & =14 \\
& \text { rejection }=2\end{aligned}$ \\
\hline
\end{tabular}

Notes + - positive implantation result 


\section{Results}

In all animals, the wounds in the lateral abdominal wall and neck areas after mesh implantation healed by primary intention. On the first day after implantation, the formation of marginal oedema was noted, which was more pronounced on the right side of the wound at the implant location. The swelling around the wound was slightly hot, painful, initially spread but by the end of the first week, it became limited and dense, with decreased soreness and local temperature. On day 12, skin sutures were removed in all animals. Subsequent observations of the animals three months after implantation of the mesh showed a partial rejection of the mesh in one bull from each group, with fragments of the mesh protruding outward $2-3 \mathrm{~mm}$ above the skin surface (Table 1). Histological analysis of the wound tissue in animals in which mesh rejection was noted in the subcutaneous tissue around the mesh fragments by sprouted connective tissue, revealed areas undergoing necrosis, such as lysis. At the periphery, these areas were limited by dense scar tissue, forming an encapsulation zone. Four months later, in wounds where the mesh was rejected, sequestration and encapsulation became even more pronounced.

\section{The results of implantation of monofilament mesh in the lateral abdominal wall}

In bulls of the first experimental group of animals, with a monofilament mesh implanted in the area of the lateral abdominal wall, showed the formation of loose connective tissue of the mesh elements after one month. In histological sections, the mesh fragments are seen as colourless, transparent, rounded or oval figures with a diameter of 40 to 60 microns. The forming granulation tissue is rich in blood vessels, with bundles of collagen fibres situated densely around the mesh elements. The cellular elements of the emerging loose connective tissue around the mesh include the dominant fibroblasts cells, followed by macrophages, lymphocytes, and single eosinophilic granulocytes.

Subsequently, after two and three months, the morphological status in the implantation zone of the monofilament mesh was approximately the same. Mesh elements were surrounded by bundles of densely formed connective tissue. A decrease in the number of cellular elements is noted, and the tissue is represented mainly by collagen structures, lymphocytes, fibroblasts, macrophages, and mast cells (Figure 1). Their thickness varied from thin to thick bundles. The bundles of collagen fibres of smaller thickness were determined for the most part from the subcutaneous fat.

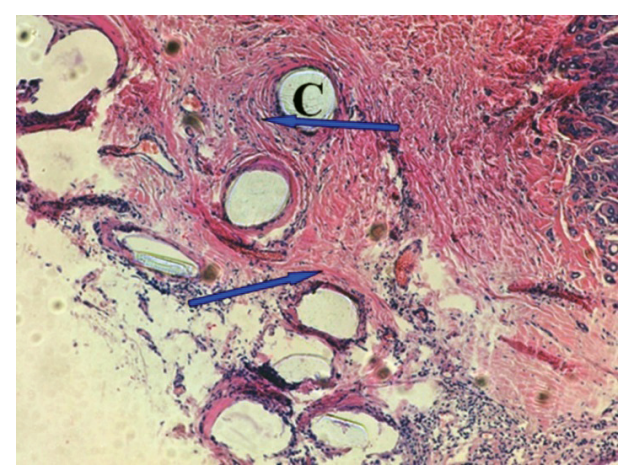

Figure 1. The bundles of collagen fibres around the mesh elements, fibroblastic cells, macrophages, lymphocytes, eosinophilic granulocytes two months after subcutaneous implantation in the lateral abdominal wall. Haematoxylin and eosin stain. Magnification 100x.

When histological sections were stained with picrofuchsin according to Van Gieson, the newly formed collagen fibres were stained bright red, indicating their maturity (Figure 2).

By the end of the experiment, after four months, rather thick rings of dense, 


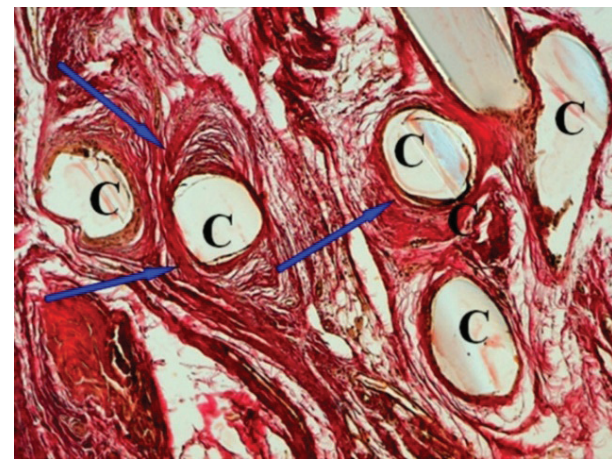

Figure 2. Mature collagen fibres around the monofilament mesh elements (C) three months after subcutaneous implantation in the region of the lateral abdominal wall of bulls. Picrofuchsin stain according to Van Gieson. Magnification $200 x$.

formed fibrous connective tissue were formed around the monofilament polypropylene mesh (Figure 3A). The newly formed connective tissue organically fit next to natural tissues, since complete fusion with them was revealed - on the one hand deep with subcutaneous fat, and on the other with the own dermal plate of the skin. Small blood vessels were detected between bundles of collagen fibres and in the surrounding tissue. The connective tissue maturation took place with collagen fibres ordered in bundles and their unidirectional orien- tation around elements of the implanted mesh. The collagen fibres folded into dense bundles of different orders (Figure 3B). The mature fibroblast cells - fibrocytes - were clearly visible between the fibrous elements.

In one test sample, the resulting connective tissue was denser than described above and it appeared fibrous (Figure 4A). It presented in the form of a very dense capsule around the elements of the implanted mesh. At this point, thick collagen fibres were formed. The number of cells decreases with respect to the collagen matrix. Cells are represented mainly by fibroblasts and macrophages, and lymphocytes and mast cells (Figure $4 \mathrm{~B})$. This is likely the result of a breach in aseptic conditions during surgery, and more pronounced inflammatory processes that developed in the focus of the mesh implant. Despite this, the elements of the implanted polypropylene monofilament mesh for hernioplasty were also very tightly encircled by the formed dense connective tissue. This fibrous-like tissue fused tightly with the surrounding tissue, and contained no blood vessels. The animal's natural tissue surrounding the implanted mesh was without pathomorphological changes.
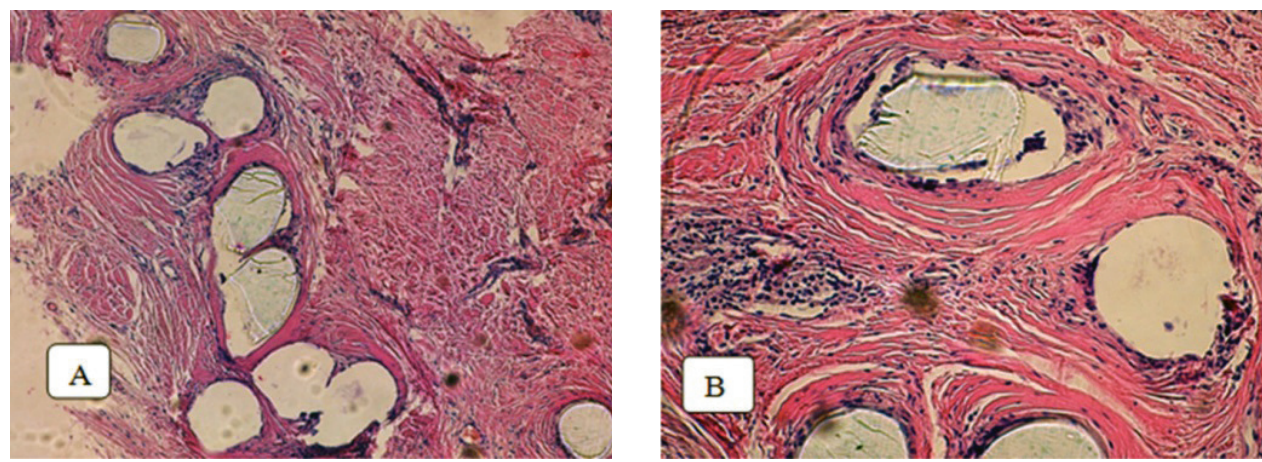

Figure 3. A. Formed bundles of collagen fibres around monofilament mesh elements four months after subcutaneous implantation in the area of the lateral abdominal wall. Stained with haematoxylin-eosin. Magnification 100x; B. Formed bundles of collagen fibres around monofilament mesh elements after four months in the area of the lateral abdominal wall. Stained with haematoxylin-eosin. Magnification 200x. 

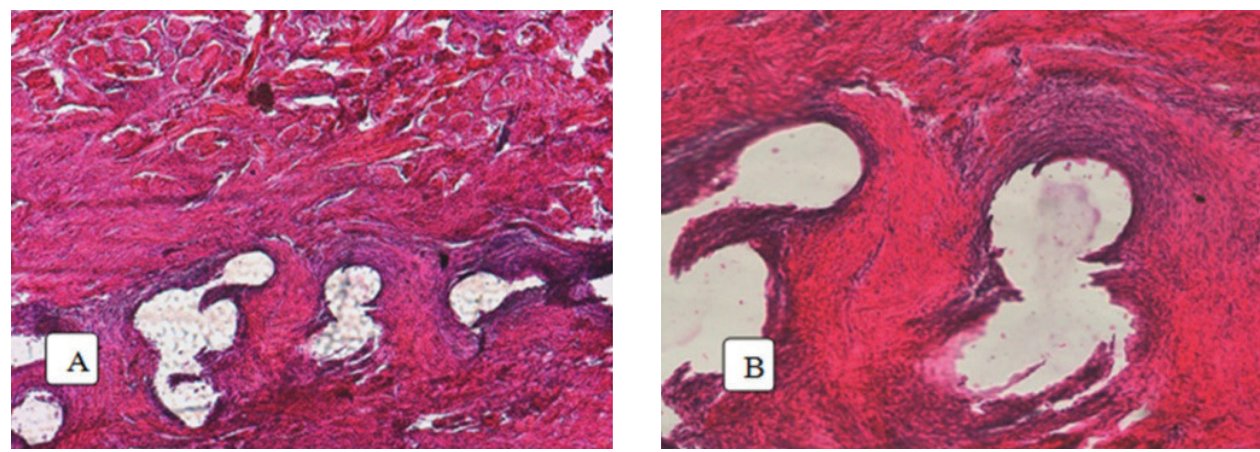

Figure 4. A. Formed bundles of collagen fibres around the monofilament mesh elements two months after subcutaneous implantation in the neck of a bull. Stained with haematoxylin-eosin. Magnification $200 x$; B. The thicker layer of collagen fibres around the monofilament mesh is presented in the form of dense scar tissue. Stained with haematoxylin-eosin. Magnification 200x.

\section{The results of implantation of monofilament mesh in the neck}

In the second experimental group, in bulls with polypropylene mesh implanted in the neck area, after one month, connective tissue was formed around the elements of the implanted mesh, with a rich network of blood vessels and a large number of cells involved in the formation of connective tissue: lymphocytes, macrophages and fibroblasts occurs. The collagen fibres are located around the elements of the implanted mesh (Table 2).
After two months, the implanted mesh elements were surrounded by bundles of dense, formed connective tissue of varying thickness (Figure 5A).

After three months, no signs of marked inflammatory processes were found in the surrounding tissues. Small blood vessels continued to be detected in a minor amount. When histological sections were stained with picrofuchsin, the newly formed collagen fibres stained bright red, indicating their maturity (Figure 6A).

Table 2. The histological structure of tissues at different intervals after implantation

\begin{tabular}{|c|c|c|c|}
\hline \multicolumn{4}{|c|}{ Results at intervals after implantation (in months) } \\
\hline 1 & 2 & 3 & 4 \\
\hline $\begin{array}{l}\text { Loose connective } \\
\text { tissue is formed } \\
\text { around the mesh. } \\
\text { A rich network } \\
\text { of blood vessels. } \\
\text { Collagen fibres } \\
\text { arranged randomly. } \\
\text { Cellular elements: } \\
\text { fibroblastic cells, } \\
\text { macrophages, } \\
\text { lymphocytes, } \\
\text { single eosinophilic } \\
\text { granulocytes. }\end{array}$ & $\begin{array}{l}\text { Dense, framed } \\
\text { connective tissue is } \\
\text { formed. Collagen } \\
\text { fibres becoming } \\
\text { mature. Cellular } \\
\text { structures are } \\
\text { mostly represented } \\
\text { by fibroblastic } \\
\text { elements. Separate } \\
\text { blood vessels } \\
\text { detected. }\end{array}$ & $\begin{array}{l}\text { A layer of formed } \\
\text { connective tissue } \\
\text { around the } \\
\text { mesh structures } \\
\text { thickens. Mature } \\
\text { collagen fibres } \\
\text { randomly oriented } \\
\text { around the mesh. } \\
\text { Separate blood } \\
\text { vessels detected. }\end{array}$ & $\begin{array}{l}\text { Thick rings of dense } \\
\text { connective tissue are } \\
\text { formed around mesh } \\
\text { elements. Collagen } \\
\text { fibres fold into bundles } \\
\text { of different orders, with } \\
\text { unidirectional orientation } \\
\text { around the mesh. The } \\
\text { network of blood vessels } \\
\text { is located between } \\
\text { bundles of collagen } \\
\text { fibres, fibroblasts are } \\
\text { also detected there. }\end{array}$ \\
\hline
\end{tabular}



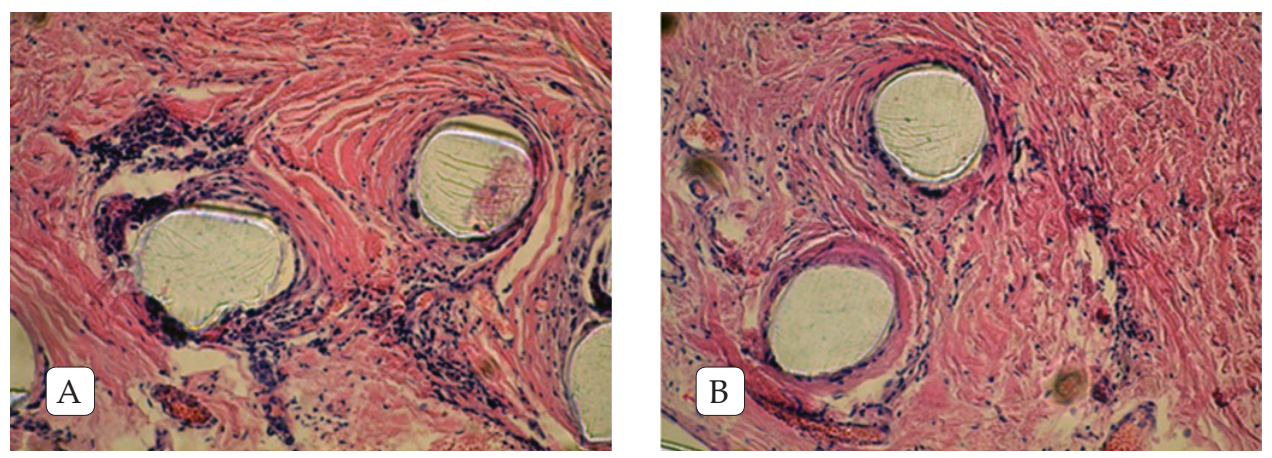

Figure 5. A. Formed bundles of collagen fibres around the monofilament mesh elements two months after subcutaneous implantation in the neck of the bull. Stained with haematoxylin-eosin. Magnification 200x; B. Formed bundles of collagen fibres around the monofilament mesh elements four months after subcutaneous implantation in the neck of a bull. Stained with haematoxylin-eosin. Magnification 200x.

Four months after surgery, the polypropylene mesh elements were surrounded by bundles of newly formed connective tissue (Figure 5B). Small blood vessels were detected between the bundles of collagen fibres and the surrounding tissue. Connective tissue maturation took place with the ordering of collagen fibres into bundles and their unidirectional orientation around the implanted mesh elements (Figure 6B).

The newly formed dense connective tissue fused tightly with the animal's dermal plate of the skin and with subcutaneous fat. This, together with

the monofilament mesh and dense connective tissue formed around it, made up a single whole. Thus, the results of this study indicate that during subcutaneous implantation of monofilament polypropylene mesh in animals, healing of surgical wounds occurs by primary intention, and proceeds with a moderate inflammatory reaction. This was seen by the fact that initially loose connective tissue formed around the mesh elements, and then was subsequently differentiated into dense scar tissue. Therefore, it can be concluded that polypropylene monofilament mesh is a suitable means
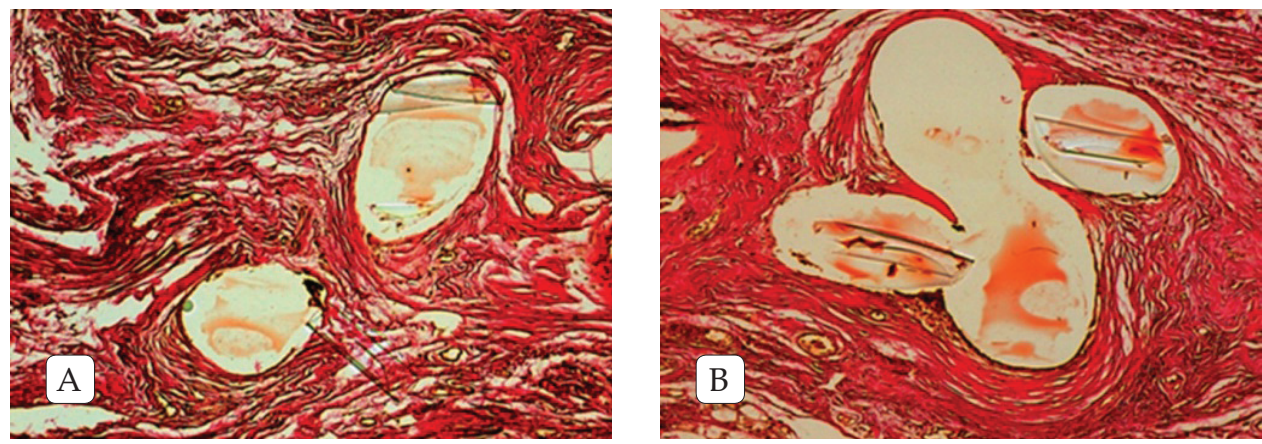

Figure 6. A. Mature collagen fibres around monofilament mesh elements three months after subcutaneous implantation in the neck of a bull. Picrofuchsin stain according to Van Gieson. Magnification 200x. B. Mature collagen fibres around monofilament mesh elements four months after subcutaneous implantation in the neck of a bull. Picrofuchsin stain according to Van Gieson. Magnification 200x. 
to close tissue defects that lead to the formation of hernias in cattle, when it is not possible to use their own tissues for these purposes.

\section{Discussion}

According to the research results, the morphological indicators of monofilament mesh implantation in cattle in the area of the abdominal wall and neck were revealed at various times after implantation after one, two, three and four months. One implant from the neck and one implant from the abdominal wall showed partial rejection at the end of the third month. After four months, one fragment of the implant jutted out of the skin by $2-3 \mathrm{~mm}$. The histological studies conducted two months after implantation found areas undergoing necrosis of the lysis type in the subcutaneous tissue around the network fragments with sprouted connective tissue. At the periphery, these areas were limited by dense scar tissue, forming an encapsulation zone. Four months later, in wounds where the mesh was rejected, sequestration and encapsulation became even more pronounced.

This can be considered a postoperative complication, resulting in encapsulation and partial rejection of the implant. In this regard, it is necessary to carefully select materials for the replacement of tissue defects and the prevention of postoperative complications in such operations (Garcia et al., 2017; Kahan et al., 2018; Matsumoto et al., 2018; Muir et al., 2018; Primus et al., 2018; Simón-Allué et al., 2018; Zhang et al., 2018). This study used a monofilament mesh, though other materials have also been used to close the hernial ring. Miserez et al. (2019) reported that three absorbable synthetic meshes are currently used: GORE BIO-A mesh (Gore), TIGR Matrix surgical mesh (Novus Scientific) and Phasix mesh (Bard). They noted that the use of absorbable synthetic meshes for the prophylaxis or treatment of abdominal wall defects in experiments on animals with small defects in their pure form seems safe, without any serious complications associated with the device during short-term observation. At the same time, they pointed out that there are no data confirming the advantages of absorbable synthetic meshes compared to the use of synthetic or biological meshes, mainly due to the lack of reliable data. Various materials are currently used to close the hernial ring, including materials derived from the human dermis $\left(\right.$ Alloderm $\left.^{\circledR}\right)$, pork dermis (Permacol ${ }^{\mathrm{TM}}$, patch A, patch D and Strattice $\left.{ }^{\circledR}\right)$, submucosa of the pig's small intestine (Surgisis ${ }^{\mathrm{TM}}$ ) and a synthetic substance (Surgipro $^{\mathrm{TM}}$ multifilament) (Pagès et al., 2018). Qiao et al. (2017) noted that their newly developed chitin patch showed good prospects for hernia treatment. Piasecka-Zelga et al. (2018) found that chitosan-modified bacterial cellulose $(\mathrm{MBC})$ is an innovative biomaterial used in regenerative medicine that can potentially improve treatment outcomes in the surgical repair of hernia, since the mesh (MBC) does not irritate or sensitize, and does not cause hypersensitivity at the site of implantation. There are also promising developments in the use of metal-based materials that are biologically safe and exhibit increased implantability, strong closure of the hernial defect, without an abnormal reaction or other complications (Gabitov et al., 2018; Mobbs et al., 2018). An important point in the surgical treatment of hernias is the prevention of postoperative complications, and in this regard, Bouliaris et al. (2019) noted that pre-treatment with $4 \%$ icodextrin and dimetindene maleate prevented postoperative complications when using polypropylene and titanium mesh materials for hernia treatment. They also noted that the use of surgical meshes to repair a ventral hernia significantly reduced the rate of hernia recurrence. 
Our morphological study indicated that there were no particular differences in the state of tissues following implantation of monofilament mesh in the neck or abdominal wall, and it was found that subcutaneous implantation of monofilament mesh in animals did not cause gross inflammatory and destructive changes in the tissues. Instead, dense fibrous tissue was formed around the mesh elements, and therefore it can be concluded that this mesh is suitable for hernioplastics in cattle. Within a month, this polypropylene monofilament mesh fused with the newly formed connective tissue, thereby forming a strong frame in the area of the hernial ring. Similar results were obtained when studying the histological results of implantation of materials for closing hernia defects in various animals (Qiao et al., 2017; Nakayama et al., 2018; Pascual et al., 2018; Ponce Leon et al., 2018; Telkes et al., 2018; Marinaro et al., 2019; Miserez et al., 2019; Trevisan et al., 2019).

The results obtained allow for a positive conclusion as to the use of implantation of monofilament mesh in the neck and abdominal wall of cattle. The healing of surgical wounds was found to proceed by primary intention. With subcutaneous implantation of monofilament polypropylene mesh, the regenerative processes of granulation tissue formation occur against a background of a moderate inflammatory reaction.

\section{Conclusions}

The study showed that there no significant differences were observed following the implantation of monofilament mesh in the abdominal wall and neck area, and morphological processes proceeded in the same manner at both implant areas. During the first month after implantation, granulation tissue resembling loose connective tissue formed around the monofilament mesh, and also showed a rich blood system and a large number of collagen fibres. The cellular elements of the emerging loose connective tissue included fibroblastic cells, macrophages, lymphocytes, eosinophilic granulocytes. Two months after implantation, the formation of friable connective tissue into the formed connective tissue continued, with maturation of collagen fibres. Cellular structures were mostly represented by fibroblastic elements, with the detection of separate blood vessels. After three months, the formed connective tissue around the mesh structures thickened. The mature collagen fibres were randomly oriented around the mesh, and separate blood vessels were detected. The composition of cellular structures remained virtually unchanged. Four months after implantation, thick rings of dense connective tissue were formed around the polypropylene mesh. The collagen fibres folded into bundles of different orders, with unidirectional orientation around the mesh. A network of blood vessels was located between bundles of collagen fibres, with the detection of fibroblasts.

Thus, when a monofilament mesh is implanted, dense fibrous tissue is formed around the mesh elements, and the mesh itself fuses with the newly formed connective tissue, forming a strong frame in the area of the hernial gates. Therefore, it can be concluded that polypropylene monofilament mesh is a suitable material for the closure of tissue defects in cattle, where it is not possible to use their own tissues for these purposes.

\section{References}

1. ALBAN, L., J. DAHL, M. ANDREASEN, J.V. PETERSEN and M. SANDBERG (2013): Possible impact of the "yellow card" antimicrobial scheme on meat inspection lesions in Danish finisher pigs. Prev. Vet. Med. 108, 334-341.

2. ALBAN, L., J. V. PETERSEN and M. E. BUSCH (2015): A comparison between lesions found during 
meat inspection of finishing pigs raised under organic/free-range conditions and conventional, indoor conditions. PHM 1, 4.

3. ANUROV, M. V., G. V. KHACHATRIAN, S. M. TITKOVA, P. S. VELANGI, M. D. POLIVODA and A. P. OETTINGER (2017): Comparative Study of Sutureless Fixation of Lightweight Surgical Meshes for Hernia Repair in a Rat Mode. B. Exp. Biol. Med. 163, 818-821.

4. AYDIN, E., R. JOSHI, M. ORIA, B. M. VARISCO, F. Y. LIM and J. L. PEIRO (2018): Fetal tracheal occlusion in mice: a novel transuterine method. J. Surg. Res. 229, 311-315.

5. BANDO, M. K. H., O. LYNNE NELSON, N. WEBSTER, H. J. BACON and R. SELLON (2018): Aortic aneurysm, dissection, and rupture in six -farmed bears. J. Zoo. Wildlife Med. 49, 738-747.

6. BLÁZQUEZ, R., F. M. SÁNCHEZ-MARGALLO, V. ÁLVAREZ, A. USÓN, F. MARINARO and J. G. CASADO (2018): Fibrin glue mesh fixation combined with mesenchymal stem cells or exosomes modulates the inflammatory reaction in a murine model of incisional hernia. Acta Biomater. 71, 318-329.

7. BOULIARIS, K., E. ASPRODINI, P. LIAKOS, A. DIAMANTIS, G. KOUKOULIS, C. BEFANI, S. TZIKA and K. TEPETES (2019): Adhesion Prevention to Polypropylene Meshes Using Combined Icodextrin Four Percent and Dimetindene Maleate. J. Surg. Res. 234, 325-333.

8. BURNS, C. G., M. S. BERGH and M. A. MCLOUGHLIN (2013): Surgical and nonsurgical treatment peritoneopericardial diaphragmatic hernia in dogs and cats: 58 cases (1999-2008). J. Am. Vet. Med. Assoc. 242, 643-650.

9. GABITOV, I. I., R. R. KHAMALETDINOV, S. G. MUDARISOV, E. R. KHASANOV, V. M. MARTYNOV, A.V.NEGOVORA, V.A.STUPIN, F. N. GALLYAMOV, I. M. FARKHUTDINOV and D. Y. SHIROKOV (2018): Improvement in Engineering Design of Machines for Biological Crop Treatment with Microbial Products. J. Eng. Appl. Sci. 13, 6500-6504.

10. GARCIA, D. P. C., S. C. NETO, C. B. NUNES, M. A. BUZELIN, A. PETROIANU, L. O. FIGUEIREDO, A. S. D. MOTTA, C. B. GASPAR and L. R. ALBERTI (2017): Comparative study of intraperitoneal adhesions related to light-weight polypropylene mesh and type i polymerized and purified bovine collagen coated light-weight polypropylene mesh in rabbits. Acta Cir. Bras. 32, 903-912.

11. GIMRANOV, V. V. and V. P. LJUKOVEC (2010): The effect of artificial implants on the healing of experimental wounds in cattle. Scientific support for the innovative development of the agroindustrial complex. Materials of the all-Russian scientific-practical conference. In the framework of the $20^{\text {th }}$ Anniversary Specialized Exhibition "AgroComplex-2010". Part II. Bashkir State Agrarian University, Ufa.

12. GREBER, D., M. DOHERR, C. DRÖGEMÜLLER and A. STEINER (2013): Occurrence of congenital disorders in Swiss sheep. Acta Vet. Scand. 55, 27.

13. HAYASHI, A. M., S. A. ROSNER, T. C. A. DE ASSUMPÇÃO, A. J. STOPIGLIA and J. M. MATERA (2016): Retrospective Study (2009-2014): Perineal Hernias and Related Comorbidities in Bitches. Top. Companion Anim. Med. 31, 130-133.

14. HODSHON, A. W. and W. B. THOMAS (2018): Transient depression of pelvic limb reflexes in dogs with acute focal thoracolumbar myelopathy. J. Am. Vet. Med. Assoc. 253, 1022-1031.

15. KAHAN, L. G., S. P. LAKE, J. M. MCALLISTER, W. H. TAN, J. YU, D. THOMPSON JR., L. M. BRUNT and J. A. BLATNIK (2018): Combined in vivo and ex vivo analysis of mesh mechanics in a porcine hernia model 2018. Surg. Endosc. 32, 820-830.

16. MARINARO, F., F. M. SÁNCHEZ-MARGALLO, V. ÁLVAREZ, E. LÓPEZ, R. TARAZONA, M. V. BRUN, R. BLÁZQUEZ and J. G. CASADO (2019): Meshes in a mess: Mesenchymal stem cell-based therapies for soft tissue reinforcement. Surg. Today 49, 316-322.

17. MATSUMOTO, S., T. HAYAKAWA, Y. KAWARADA, K. UCHIDA, T. EGUCHI, H. WADA, N. UENO, H. IDANI, K. NAKANO and Y. OOMOMO (2018): Proper training in laparoscopic hernia repair is necessary to minimize the rising recurrence rate in Japan. Asian J. Endosc. Surg. 11, 151-154.

18. MISEREZ, M., A. P. JAIRAM, G. S. A. BOERSEMA, Y. BAYON, J. JEEKEL and J. F. LANGE (2019): Resorbable Synthetic Meshes for Abdominal Wall Defects in Preclinical Setting: A Literature Review. J. Surg. Res. 237, 67-75.

19. MOBBS, R.J.,P.J.RAO,K.PHAN, P.HARDCASTLE, W. J. CHOY, E. R. MCCARTNEY, R. K. DRUITT, C. A. L. MOUATT and C. C. SORRELL (2018): Anterior Lumbar Interbody Fusion Using Reaction Bonded Silicon Nitride Implants: Long-Term Case Series of the First Synthetic Anterior Lumbar Interbody Fusion Spacer Implanted in Humans. World Neurosurg. 120, 256-264.

20. MUIR, K. B., C. P. SMOOT, J. L. VIERA, M. R. SIRKIN, B. YOON, J. BADER, R. SMILEY, D. HOLT and L. J. HOFMANN (2018): Determination of proper timing for the placement of intra-abdominal mesh after incidental enterotomy in a rodent model (Rattus norvegicus). Am. Surgeon 84, 593-598.

21. NAKAYAMA, Y., N. OSHIMA, E. TATSUMI, O. ICHII and T. NISHIMURA (2018): iBTA-induced bovine Biosheet for repair of abdominal wall defects in a beagle model: proof of concept. Hernia 22, 1033-1039.

22. PAGÈS, G., P. MENAUT and J. G. GRAND (2018): Peritoneopericardial diaphragmatic hernia in the dog: A clinical report in a litter of six Dogue de Bordeaux puppies. Rev. Vet. Clin. 53, 39-43.

23. PASCUAL, G., C. MESA-CILLER, M. RODRIGUEZ, B. PEREZ-KOHLER, V. GOMEZ-GIL, M. FERNANDEZ-GUTIERREZ, J. S. ROMAN and J. M. BELLON (2018): Pre-clinical assay of the tissue integration and mechanical adhesion of several 
types of cyanoacrylate adhesives in the fixation of lightweight polypropylene meshes for abdominal hernia repair. PLoS One 13, e0206515.

24. PIASECKA-ZELGA, J., P. ZELGA, J. SZULC, J. WIETECHA and D. CIECHAŃSKA (2018): An in vivo biocompatibility study of surgical meshes made from bacterial cellulose modified with chitosan. Int. J. Biol. Macromol. 116, 1119-1127.

25. PONCE LEON, F., J. E. F. MANSO, V. L. ABUD, W. NOGUEIRA, P. C. SILVA and R. MARTINEZ (2018): Sublay repair results in superior mesh incorporation and histological fibrogenesis in comparison to onlay and primary suture in an experimental rat model. Hernia 22, 1089-1100.

26. PRIMUS, F. E., D. M. YOUNG, J. P. GRENERT and H. W. HARRIS (2018): Silver microparticles plus fibrin tissue sealant prevents incisional hernias in rats. J. Surg. Res. 227, 130-136.

27. QIAO, J., Z. JIANG, Y. YANG, J. CHI, X. QIAO, B. HAN and W. LIU (2017): Study of a new biodegradable hernia patch to repair abdominal wall defect in rats. Carbohyd. Polym. 172, 255-264.

28. SADAN, M., E.-S. EL-SHAFAEY and S. ELKHODERY (2019): Abdominal hernias in camel (Camelus dromedaries): Clinical findings and treatment outcomes. J. Vet. Med. Sci. 81, 675-681.

29. SAFONOV, V. A. (2018). Biological Role of Selenium and Correction Effects of Its Content in the Organism of Animals. Geochem. Int. 56, 10461050.

30. SCHARNER, D., C. GITTEL, K. WINTER, I. VERVUERT and W. BREHM (2018): Comparison of incisional complications between skin closures using a simple continuous or intradermal pattern: A pilot study in horses undergoing ventral median celiotomy. PeerJ 11, e5772.

31. SHNJAKINA, T. N. and N. P. SHHERBAKOV (2008): Abdominal hernias in animals. Ural State Academy of Veterinary Medicine, Troick, $140 \mathrm{p}$.

32. SIMÓN-ALLUÉ, R., A. ORTILLÉS and B. CALVO (2018): Mechanical behavior of surgical meshes for abdominal wall repair: In vivo versus biaxial characterization. J. Mech. Behav. Biomed. Mat. 82, 102-111.
33. SNELL, W. L., R. J. ORSHER, M. P. LARENZAMENZIES and C. A. POPOVITCH (2015): Comparison of caudal and pre-scrotal castration for management of perineal hernia in dogs between 2004 and 2014. New Zeal. Vet. J. 63, 272-275.

34. TAGUCHI, T., Y. YANAGI, K. YOSHIMARU, X. Y. ZHANG, T. MATSUURA, K. NAKAYAMA, E. KOBAYASHI, H. YAMAZA, K. NONAKA, S. OHGA and T. YAMAZA (2019): Regenerative medicine using stem cells from human exfoliated deciduous teeth (SHED): a promising new treatment in pediatric surgery. Surg. Today 49, 316-322.

35. TELKES, G., K. DEZSÖ, A. DOROS and Z. MATHE (2018): Successful Treatment of the Gastrointestinal Manifestation of Prototheca in a Kidney Transplant Recipient: A Case Report. Transpl. P. 50, 3928-3931.

36. TREVISAN, C., E. MAGHIN, A. DEDJA, P. CACCIN, N. DE CESARE, C. FRANZIN, D. BOSO, P. PESCE, F. CAICCI, F. BOLDRIN, L. URBANI, P. DE COPPI, M. POZZOBON, P. PAVAN and M. PICCOLI (2019): Allogenic tissue-specific decellularized scaffolds promote long-term muscle innervation and functional recovery in a surgical diaphragmatic hernia model. Acta Biomater. 89, 115-125.

37. VORTMANN, T. F. and O. DISTL (2016): Occurrence and reasons of congenital umbilical hernias in cattle. Prakt. Tierarzt. 97, 620-627.

38. WINTER, V., B. DEGASPERI, B. BOCKSTAHLER and G. DUPRÉ (2019): Suture length to wound length ratio in 175 small animal abdominal midline closures. PLoS One 14, e0216943

39. YUN, J., S. OLKKOLA, M.-L. HÄNNINEN, C. OLIVIERO and M. HEINONEN (2017): The effects of amoxicillin treatment of newborn piglets on the prevalence of hernias and abscesses, growth and ampicillin resistance of intestinal coliform bacteria in weaned pigs. PLoS One 12, e0172150.

40. ZHANG, W., Y. LI, D. JIANG, S. XIE, M. ZENG, J. CHEN, L. CHEN, H. OUYANG and X. ZOU (2018): Promotion of Hernia Repair with High-Strength, Flexible, and Bioresorbable Silk Fibroin Mesh in a Large Abdominal Hernia Model. ACS Biomater.Sci. Eng. 4, 2067-2080. 


\section{Morfološki indikatori potkožne implantacije monofilamentne mrežice}

Dr. sc. Valiyan GIMRANOV, dr. med. vet., redoviti profesor, dr. sc. Evgeny SKOVORODIN, dr. med. vet., redoviti profesor, Ilnara ABYZGILDINA, student, dr. sc. Foat KARIMOV, dr. med. vet., redoviti profesor, dr. sc. Aidar BAGAUTDINOV, dr. med. vet., redoviti profesor, Bashkir State Agrarian University, Ufa, Rusija

Hernije su često, nezarazno stanje životinja. U produktivnih životinja, ukoliko se ne pruži kirurško liječenje, dolazi do preranog odbacivanja ploda i potencijalnog gubitka njihove produktivne dugovječnosti. U malih kućnih ljubimaca ovo je postalo socijalni problem za vlasnike kućnih ljubimaca povezan s čuvanjem i smrću oboljelih životinja. Cilj ove studije bio je proučiti histološke parametre tkiva tijekom implantacije monofilamentne mrežice u goveda za razdoblja do četiri mjeseca. Studija je provedena na osam bikova Black Motley pasmine, podijeljenih u dvije skupine od po četiri životinje. U prvoj skupini, četiri su bika dobila potkožno implantiranu mrežicu za hernioplastiku izrađenu od polipropilenskog monofilamenta (Herniamesh S.R.I. Via CiRie 22/A, San Maruro Torinese, Torino, Italija) na području bočne meke abdominalne stijenke s desne i lijeve strane. U drugoj skupini, četiri su bika dobila implantate u srednjoj trećini vrata na desnoj i lijevoj strani. Time je predmet istraživanja bilo 16 rana $\mathrm{s}$ implantiranim mrežicama. Sterilni komad monofilamentne mrežice, $1 \times 2 \mathrm{~cm}$ veličine i preklopljen na pola duž uzdužne strane, umetnut je okomito $\mathrm{u}$ formirani hipodermički džepić s desne strane rane, u koji je bilo moguće slobodno postaviti spomenutu mrežicu. U studiji je rabljena nit polikon br. $4 \mathrm{~s}$ isprekidanim čvornim šavovima te su primijenjena tri šava. Kako bi se osiguralo fiksiranje mrežice, ona je središnje zašivena. Materijal za histološke studije uzet je biopsijom jedan, dva, tri i četiri mjeseca nakon implantacije. Tkivo je uronjeno u parafinske blokove, a isječci tkiva obojeni su hematoksilin-eozinom i pikrofuksinom prema Van Giesonu. Rezultati su pokazali da nakon potkožne implantacije monofilamentne mrežice $\mathrm{u}$ vrat $\mathrm{i}$ abdominalnu stijenku goveda dolazi do liječenja rane prema primarnoj namjeri. Otkriveno je da je od početka histološke studije do kraja prvog mjeseca, monofilamentna mrežica prvo obrasla labavim veznim tkivom. Do kraja studije, nakon četiri mjeseca, to tkivo se sekvencijski diferenciralo $\mathrm{u}$ gusto vezno tkivo. Nisu zamijećene velike razlike između područja abdominalne stijenke i vrata u smislu mjesta implantacije, a morfološki procesi na oba mjesta odvijali su se jednako. Stoga nam provedena studija dopušta donijeti zaključak da je monofilamentna mrežica prikladan materijal za zatvaranje kilnog prstena $u$ stoke, ako nije moguće, $u$ tu svrhu, rabiti njihovo vlastito tkivo.

Ključne riječi: stanica, derma, epiderma, liječenje, implantat 